\title{
Changes in toxin content, biomass and pigments of the dinoflagellate Alexandrium minutum during nitrogen refeeding and growth into nitrogen or phosphorus stress
}

\author{
Krystyna Flynn ${ }^{1}$, José M. Franco ${ }^{2}$, Pablo Fernández ${ }^{3}$, Beatriz Reguera $^{3}$, \\ Manuel Zapata ${ }^{4}$, Gareth Wood ${ }^{1}$, Kevin J. Flynn ${ }^{1, *}$ \\ ${ }^{1}$ Algal Research Unit, School of Biological Sciences, University of Wales Swansea, Singleton Park, Swansea SA2 8PP, \\ United Kingdom \\ ${ }^{2}$ Instituto de Investigaciones Marinas (C.S.I.C.), Eduardo Cabello 6, E-36208 Vigo, Spain \\ ${ }^{3}$ Instituto Español de Oceanografía, Aptdo. 1552, E-36260 Vigo, Spain \\ ${ }^{4}$ Centro de Investigaciones Mariñas (Xunta de Galicia), Aptdo. 208, Villagarcía de Arousa, E-36600 Pontevedra, Spain
}

\begin{abstract}
Two strains of the paralytic shellfish toxin (PST) producing dinoflagellate Alexandrium minutum Halim (highly toxic AL1V and weakly toxic AL2V) were grown in batch culture with either nitrate or phosphate as the limiting nutrient. In comparison with cells of the strain AL1V, cells of AL2V grew at a similar $\mathrm{C}$-specific rate, had a higher $\mathrm{C} / \mathrm{N}$ ratio, and lower ratios of $\mathrm{chl} \mathrm{a/chl} \mathrm{c}_{2}$ and $\mathrm{chl} a /$ peridinin. Neither chlorophylls nor carotenoids could be used to estimate C-biomass, $\mathrm{N}$-biomass or toxin content for this organism. The toxin profile for both strains was dominated (up to $95 \%$ ) by the gonyautoxin GTX4, with smaller proportions of GTX1, GTX2 and GTX3. The rate of toxin synthesis for both strains was greatest 1 to $2 \mathrm{~d}$ after the $\mathrm{N}$-refeeding of $\mathrm{N}$-deprived cells, with the net rate of toxin synthesis exceeding that of $\mathrm{C}$-biomass and cell division by a factor of up to 4 . Toxin synthesis was not enhanced by short-term P-stress. N-stress alone led to a decrease in toxin cell ${ }^{-1}$, but P-stress followed by $\mathrm{N}$-stress did not result in such a decline, implicating phosphorus in the regulation of toxin metabolism. Although arginine is a major precursor for PST synthesis, taurine, glycine, glutamine, and cell N showed similar relations to that observed for arginine with respect to toxin content. Furthermore, the mole ratio of arginine/toxin could vary by a factor of up to 5 between AL1V and AL2V at peak values of toxin cell-1, and by more than 5 within a strain when growing under different conditions. These observations suggest that the relationship between free arginine content and toxin content is complex. No explanation for the higher toxin content of AL1V is apparent, except that AL1V has a higher $\mathrm{N}$-content per cell and this may be conducive to a higher rate of synthesis of the $\mathrm{N}$-rich toxins.
\end{abstract}

KEY WORDS: Dinoflagellate - Alexandrium minutum - Paralytic shellfish poisons PSP toxin - Amino acid P Pigment $\cdot$ Algal growth dynamics

\section{INTRODUCTION}

The formation of algal blooms is usually associated with a decline of nutrients; yield nutrient-limitation is considered usually to be due to a lack of nitrogen or phosphate. Dinoflagellate blooms occur in low-turbulent conditions, often associated with frontal systems or inshore stratified water columns (Margalef 1978, Mar-

\footnotetext{
-Addressee for correspondence
}

galef et al. 1979, Holligan et al. 1984, LeFévre 1986). Offshore populations advected into coastal embayments may be expected to encounter changes in the availability of nutrients, while near-shore populations may also encounter changes in environmental conditions during intrusions of offshore waters and during increased riverine inputs. Migration to and from nutriclines offers additional opportunities to encounter transients in nutrient availability (Paasche et al. 1984).

The dinoflagellate Alexandrium minutum forms red tides in the Galician northern rias (Rías Altas, NW 
Spain; species referred to as Gonyaulax tamarensis in Blanco et al. 1985 and as Alexandrium lusitanicum in Franco et al. 1992) and is associated with paralytic shellfish poisoning (PSP) toxicity near to closure limits for the bivalve industry [ $80 \mu \mathrm{g}$ saxatoxin (STX) equivalent per $100 \mathrm{~g}$ meat] in the Galician southern rias (Rías Bajas, NW Spain). These particular blooms originate within the rias following periods of elevated terrestrial run-off and subsequent haline stratification (Reguera et al. 1991). The distribution of $A$. minutum includes other areas of the European Atlantic coast (Erard-Le Denn 1991), the Mediterranean (Delgado et al. 1990, Montresor et al. 1990) and off Australia (Hallegraeff et al. 1991).

Two strains of Alexandrium minutum (both isolated from the Ría de Vigo, NW Spain), one of which (AL1V) is more toxic than the other (AL2V), were the subjects of the study reported here. The objectives of this study were: (1) to consider the effects on toxin content of $\mathrm{N}$ stress and P-stress, and of $\mathrm{N}$-refeeding of $\mathrm{N}$-deprived A. minutum cells, (2) to look for gross differences between the 2 strains which may affect toxin synthesis, and (3) to consider the use of pigments to monitor biomass and the toxin content of this species.

The main parameters considered were toxin content, changes in the intracellular amino acid pool (arginine is an important intermediary in PSP toxin synthesis; Shimizu et al. 1990), biomass and pigmentation. Emphasis has been placed previously on the effects of nutrient limitation on Alexandrium spp. (Boyer et al. 1987. Anderson et al. 1990). This paper reports for the first time the important effect of $\mathrm{N}$-refeeding on toxin synthesis in $A$. minutum.

\section{MATERIALS AND METHODS}

Alexandrium minutum Halim strains AL1V and AL2V (Instituto Español de Oceanografía, Vigo, Spain) were grown at $15^{\circ} \mathrm{C}$ in modified $\mathrm{K}$ medium (Keller \& Guillard 1985) based on local aged seawater with different amounts of nitrate and inorganic phosphate, and with no artificial buffer, ammonium or organic phosphate. The experiments were conducted on 3 occasions. Experiment I (Expt I) was conducted in Swansea (UK) with only strain AL1V which had been transferred from Vigo (Spain) 5 mo earlier. In that study, the growth media contained either $100 \mu \mathrm{M}$ nitrate $+20 \mu \mathrm{M}$ phosphate (low-N/high-P), or $200 \mu \mathrm{M}$ nitrate $+5 \mu \mathrm{M}$ phosphate (high-N/low-P). Because the cells growing in the high-N/low-P medium in Expt $I$ actually exhausted both $\mathrm{N}$ and $\mathrm{P}$, for Expt II, conducted in Vigo with strains AL1V and AL2V, the high-N/low-P media contained $300 \mu \mathrm{M}$ nitrate $+5 \mu \mathrm{M}$ phosphate. Expt III, conducted in Swansea, also included strains of non- toxic $A$. tamarense and $A$. affini, considered additional parameters, and was of longer duration. Expt III used the same nitrate + phosphate combinations as Expt II. Only the results from Expt III pertaining to toxin content in $A$. minutum are presented here.

The growth media were filtered through $0.22 \mu \mathrm{m}$ filters (Durapore, Millipore) rather than autoclaved. Inoculation of the experimental flasks (5 l) was with cells previously grown in the low-N/high-P medium; these cultures were $\mathrm{N}$-deprived with elevated $\mathrm{C} / \mathrm{N}$ ratios, thus Day 0 in the figures also indicates the point of N-refeeding. Cultures were grown with no forced aeration, sampled via a syphon tube and illuminated in a $12 \mathrm{~h} / 12 \mathrm{~h}$ light/dark cycle either at $180 \mu \mathrm{mol} \mathrm{m} \mathrm{m}^{-2} \mathrm{~s}^{-1}$ (Expt I), or at $200 \mu \mathrm{mol} \mathrm{m} \mathrm{m}^{-2} \mathrm{~s}^{-1}$ (Expts II \& III).

Cells were counted in a Sedgewick-Rafter chamber after fixing with Lugol's iodine and, for Expt III, also by Elzone 282 PC particle analyzer. Nitrate and phosphate were analyzed using an Alpkem RFA-2 microsegmented-flow nutrient analyzer. Extracted pigments were analyzed either by spectrophotometry for Expts I \& III (extracted into dimethylformamide and using the equations of Strickland \& Parsons 1972), or by HPLC for Expt II [extraction as in Flynn et al. (1993), and HPLC according to Zapata et al. (1987) with quantification using the specific absorption coefficients given by Jeffrey \& Humphrey (1975) and Jeffrey et al. (1975)]. Intracellular free amino acids (InAA) were analyzed by HPLC according to the methods of Flynn \& Flynn (1992) with derivatization and injection performed by a Hitachi AS-4000 autosampler fitted with a Peltier cooling system. Cellular $\mathrm{C}$ and $\mathrm{N}$ were measured in samples collected on preashed $\left(450^{\circ} \mathrm{C}\right.$ for $\left.6 \mathrm{~h}\right)$ $13 \mathrm{~mm}$ diameter GA/E (Gelman) glassfibre filters using Europa Scientific RoboPrep and TracerMass instruments with isoleucine as the standard.

Cells for toxin analysis were collected on preashed $\mathrm{GA} / \mathrm{E}$ filters and extracted 3 times with $0.1 \mathrm{M}$ acetic

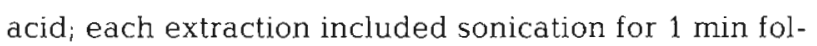
lowed by freezing and thawing. The extract was centrifuged and the supernatant adjusted to $\mathrm{pH} 3$ to 4 . PSP toxins for Expts I \& II were analyzed by a postcolumn derivatization method (second isocratic method described by Franco \& Fernández-Vila 1993). For Expts I \& III, toxin content was also estimated using a precolumn periodate oxidation (modified after Lawrence et al. 1991), with separation on a HPLC Technology Ultratechsphere C18 ODS column with mobile phases containing acetate buffer, methanol and tetrahydrofuran.

Parameter-specific rates of increase ('growth rates') were computed according to the formula

$$
\text { Parameter- } \mu=\left[\ln \left(P_{t_{1}}\right)-\ln \left(P_{t_{0}}\right)\right] /\left(t_{1}-t_{0}\right)
$$

where $P_{t_{0}}$ and $P_{t_{1}}$ are values of the parameter at times $t_{0}$ and $t_{1}$ respectively (time in days). 
Fig. 1. Alexandrium minutum. Changes in (a) cell number and cell-specific growth rate (cell- $\mu$ ), and (b) carbon cell ${ }^{-1}$ and $\mathrm{C} / \mathrm{N}$ ratio for cells of strain AL1V grown in low-N/high$\mathrm{P}$ media (open symbols) and high-N/low-P media (closed symbols) during Expt II. Cells exhausted nutrients, and thus became $\mathrm{N}$ deprived $(\mathrm{N}-\mathrm{dp})$ or $\mathrm{P}$-deprived $(\mathrm{P}-\mathrm{dp})$, at the times indicated

Fig. 2. Alexandrium minutum. Changes in (a) cell number and cell-specific growth rate (cell- $\mu$ ), and (b) carbon cell ${ }^{-1}$ and $\mathrm{C} / \mathrm{N}$ ratio for cells of strain AL2V grown in low-N/high$\mathrm{P}$ media (open symbols) and high-N/low-P media (closed symbols) during Expt II. Abbreviations as in Fig. 1
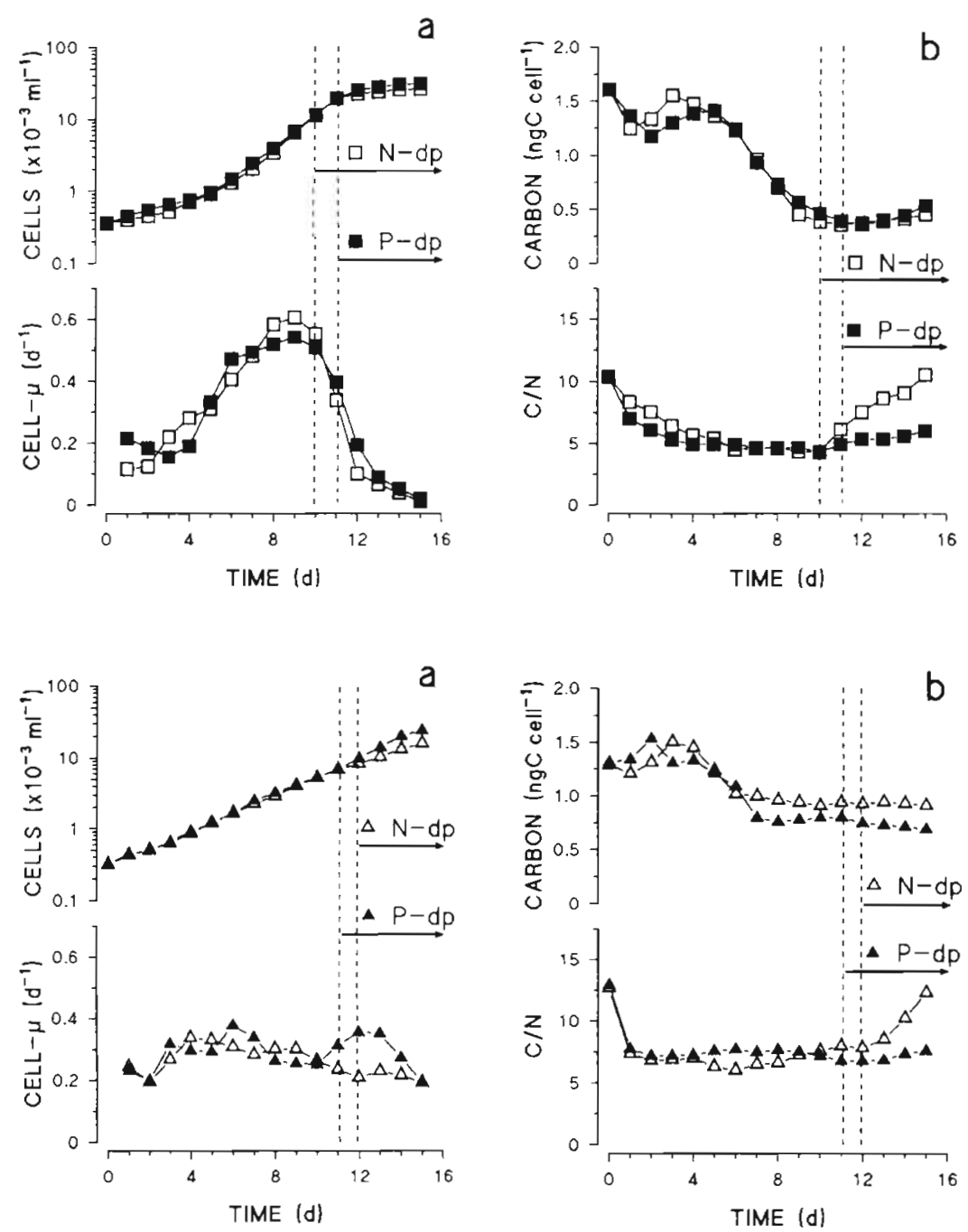

Biomass

Statistical testing of comparisons were performed using ANOVA or joint regression analysis as indicated.

\section{RESULTS}

\section{Cell growth}

In Expt I, cells of strain AL1V in both nutrient regimes ceased growth at a cell density of $21000 \mathrm{ml}^{-1}$, achieving similar maximum cell- $\mu$ of around $0.5 \mathrm{~d}^{-1}$. In Expt II, AL1V attained $25000 \mathrm{ml}^{-1}$ with cell- $\mu$ of $0.2 \mathrm{~d}^{-1}$ for the first part of the culture but then rising to around $0.5 \mathrm{~d}^{-1}$ between Days 7 and 11 (Fig. 1a). AL2V grew slower and did not reach stationary phase by the end of the study period; maximum cell densities were in excess of $20000 \mathrm{ml}^{-1}$ with a maximum cell- $\mu$ around $0.3 \mathrm{~d}^{-1}$ (Fig. 2a). Cell numbers in Expt III, which continued for $27 \mathrm{~d}$, reached $25000 \mathrm{ml}^{-1}$, with maximum cell- $\mu$ values of 0.4 for both AL1V and AL2V.
AL1V in both nutrient regimes in Expt I contained a maximum of $1 \mathrm{ng} \mathrm{C}$ cell $^{-1}$ (achieving a maximum $\mathrm{C}-\mu$ in excess of $0.4 \mathrm{~d}^{-1}$ ), falling to half that when growth slowed. The minimum $\mathrm{C} / \mathrm{N}$ ratio was 4 , rising to 14 after $10 \mathrm{~d}$ of $\mathrm{N}$-deprivation in the low-N/high-P culture, and with a slower rate of increase to a $\mathrm{C} / \mathrm{N}$ ratio of 9 after $7 \mathrm{~d}$ of $\mathrm{N}$-deprivation in the high-N/low-P culture which exhausted its nitrate $3 \mathrm{~d}$ after exhausting the phosphate.

Cells of AL1V in Expt II were up to $20 \%$ larger than those in Expt I, containing $1.2 \mathrm{ng} \mathrm{C} \mathrm{cell}^{-1}$ during the first part of the culture, falling to $0.4 \mathrm{ngC} \mathrm{cell}^{-1}$ (Fig. 1b). C- $\mu$ remained around $0.25 \mathrm{~d}^{-1}$ between 3 and $11 \mathrm{~d}$ with a $\mathrm{C} / \mathrm{N}$ of 4 to 5 (Fig. 1b). The increased cell- $\mu$ (from 0.2 to $0.5 \mathrm{~d}^{-1}$ ) for AL1V in the latter part of the growth curve was enabled by a decrease in average biomass per cell (Fig. 1b) and not by an increase in 

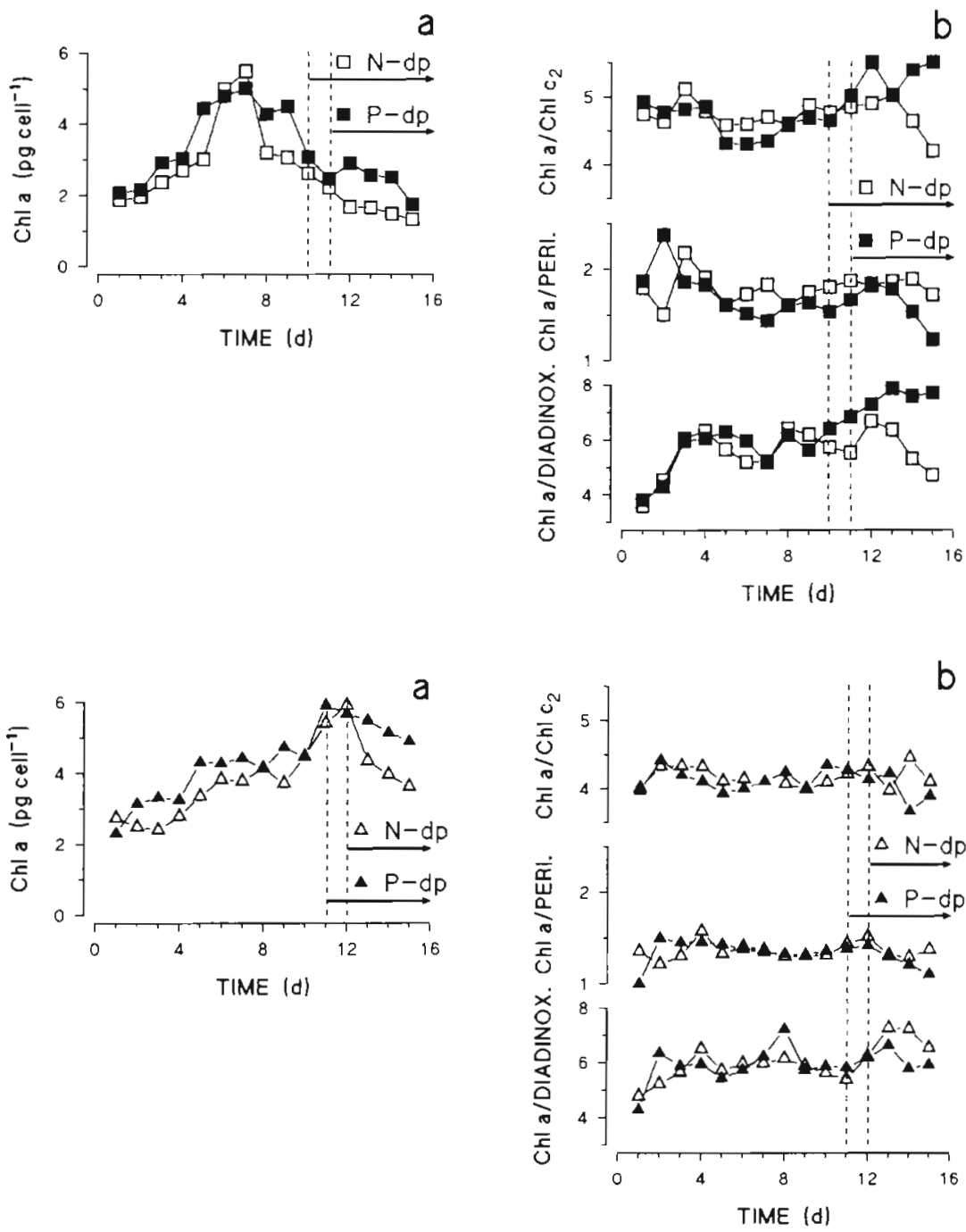

Fig. 3. Alexandrium minutum. Changes in (a) the content of chl $a$ and (b) the mass ratio of chla/chl $c_{2}$, chla/peridinin and chla/diadinoxanthin for cells of strain AL1V during Expt II. Other details as in Fig. 1
Fig. 4. Alexandrium minutum. Changes in (a) the content of chI $a$ and (b) the mass ratio of chla/chl $c_{2}$, chla/peridinin and chl a/diadinoxanthin for cells of strain AL2V during Expt II. Other details as in Fig. 1
C- $u$. Cells of AL2V had a maximum C content similar to that of AL1V in Expt II ( $p>0.95$ by ANOVA), but the minimum $C$ content was greater ( $p>0.95$ by ANOVA) at $0.8 \mathrm{ng} \mathrm{C}$ cell $^{-1}$ with $0.1 \mathrm{ngN}$ cell $^{-1}$ (Fig. 2b). The minimum $\mathrm{C} / \mathrm{N}$ ratio was greater for $\mathrm{AL2V}$ than for AL1V ( 7 compared to 4.7 ; $p>0.95$ by ANOVA and by joint regression analysis; Figs. $1 b$ \& 2b). In Expt II, the cells growing in high-N/low-P media did not exhaust their nitrate, but the $C / N$ ratios in the low-N/high-P cultures showed increases the day after the nitrate was exhausted (Figs. 1b \& 2b).

In Expt III, cell sizes were larger again (30\% larger than those in Expt II), but again minimum $\mathrm{C} / \mathrm{N}$ ratios for AL1V (4.5 to 5) were less than for AL2V (6.7 to 7.4). As noted in Expt II, cells of AL2V grown in the highN/low-P cells had a significantly higher minimum $\mathrm{C} / \mathrm{N}$ ratio ( $p>0.95$ by joint regression analysis). Cells of both strains grown in low-N/high-P media and subjected to prolonged $\mathrm{N}$-deprivation had half the $\mathrm{C}$ content of those grown in the high-N/low-P media (0.6 vs $1.2 \mathrm{ng} \mathrm{C} \mathrm{cell}{ }^{-1}$ ).
$\mathrm{C} / \mathrm{P}$ values for P-replete cells were computed from $\mathrm{C}$-biomass and phosphate removed from the media to be around 25 to 30 , with $\mathrm{C} / \mathrm{P}$ exceeding 80 in all $\mathrm{P}$ deprived cells.

\section{Pigments}

Cells of strain AL1V in Expt I contained 7 pg chlorophyll a (chl a) cell ${ }^{-1}$ during exponential growth, falling rapidly on exhaustion of nitrate in both the lowN/high-P and high-N/low-P cultures, with the ratio of $\mathrm{chl}$ a/chl $c$ remaining at 5 throughout (not shown).

The pigments of the cells in Expt II were analyzed by HPLC. The chl a content of AL1V (Fig. 3a) increased from $2 \mathrm{pg}$ chl a cell ${ }^{-1}$ to peak at around $5 \mathrm{pg}$ at $6 \mathrm{~d}$ (with a value of chla- $\mu$ twice that of cell- $\mu$ ) before declining to below $1.5 \mathrm{pg}$ for the low-N/high-P cells and $2.5 \mathrm{pg}$ for high-N/low-P cells. ChI a in strain A.L2V increased steadily from 2.5 to $5.5 \mathrm{pg} \mathrm{chl} \mathrm{a} \mathrm{cell}^{-1}$ by $12 \mathrm{~d}$, declining more rapidly on nitrate exhaustion than on phosphate exhaustion (Fig. 4a). The amounts of the 
other pigments ( $\mathrm{chl} c_{2}$, and the carotenoids peridinin and diadinoxanthin) covaried with that of chl a for both strains (Figs. 3b \& 4 b) although the relative proportions of chl $a / c h l C_{2}$ and chl a/peridinin differed between the strains ( $p>0.95$ by ANOVA). Thus, the ratio of $\mathrm{chl} a / \mathrm{chl} c_{2}$ remained steady at 4.5 to 5 for AL1V and 4 to 4.5 for AL2V, while the ratio of $\mathrm{chl}$ a/peridinin remained around 1.7 for AL1V and 1.4 for AL2V.

\section{Toxins}

Toxins from AL1V in Expt I were analyzed by a precolumn oxidation method and by a postcolumn derivatization method. A comparison between these methods showed similar results for total toxin content (Fig. 5), with a correlation coefficient ( $r$ ) of 0.91 . The precolumn results have been calibrated against those from the postcolumn analysis of toxin standards.

Total toxin cell ${ }^{-1}$ for both cultures of AL1V in Expt I reached a peak at $4 \mathrm{~d}$ and thereafter declined to $30 \%$ of that value (Fig. 5). There was no significant difference with respect to total toxin content between the cells grown in the different nutrient regimes, although towards the end a divergence may have been developing (with high-N/low-P cells having a higher toxin content). The toxin composition was dominated by the gonyautoxins GTX4 (60\%) and GTX1 (20 to $30 \%)$ with smaller amounts of GTX3 and GTX2. With increasing $\mathrm{N}$-starvation the proportion of GTX4 increased (in the low-N/high-P cells to $78 \%$ ) with a pro rata decline in its isomeric form, GTX1.

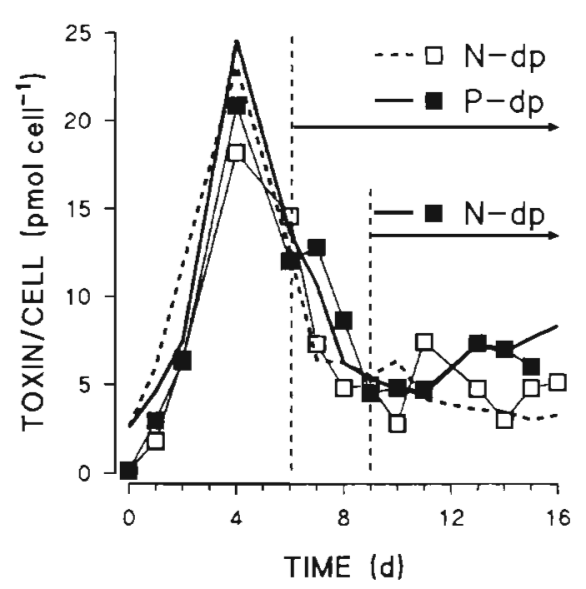

Fig. 5. Alexandrium minutum. Changes in total toxin cell-1 in cells of strain AL1V during Expt I. Cells grown in the low-N/high-P media (open symbol and heavy dashed line) became $\mathrm{N}$-deprived ( $\mathrm{N}$-dp) at Day 6 , and cells in the highN/low-P media (closed symbols and heavy continuous line) became P-deprived (P-dp) at Day 6 and $\mathrm{N}$-deprived at Day 9. Symbols denote data from post-column HPLC; heavy dashed and continuous lines denote data from precolumn HPLC
A comparison of changes in parameter-specific rates of increase, shown in Fig. 6 for the low-N/high-P culture of AL1V in Expt I, shows that the increase in toxin cell $^{-1}$ in the pre-exponential growth phase was concurrent with rapid changes in nitrogen- $\mu$ and arginine$\mu$ as the cells recovered from $\mathrm{N}$-deprivation, before $\mathrm{C}$ content and cell division increased.

Similar changes in toxin cell ${ }^{-1}$ and in toxin- $\mu$ were seen for both strains AL1V and AL2V in Expt II (Fig. $7 \mathrm{a}, \mathrm{b}$ ). Toxin content in AL2V was $20 \%$ of that in AL1V at most. The cause of the higher toxicity in the low-N/high-P cells of AL1V in Expt II (open symbols, Fig. 7a) is not known. In neither strain did short-term $\mathrm{N}$-deprivation or P-deprivation promote increases in toxin content. In contrast with the toxin profile in Expt I, those of the cells for both AL1V and AL2V in Expt II were dominated by GTX4 (over $90 \%$ ) with only around $5 \%$ GTX1 and trace amounts of GTX3 and GTX2. These proportions varied by only a few percent during the experiment.

The duration of Expt III was twice that of the previous studies and, as occurred during Expt I, the highN/low-P cultures exhausted first the phosphate and then the nitrate, while the low-N/high-P exhausted nitrate only. Expt III thus shows the effects on synthesis and turnover of toxin during $\mathrm{N}$-deprivation alone and after a period of P-deprivation. Again, net toxin synthesis halted on $\mathrm{N}$-exhaustion, and on prolonged $\mathrm{N}$-deprivation, levels of toxin in the culture declined (Figs. 8a \& 9a). However, this was not so for cells which exhausted nitrate after they had already ex-

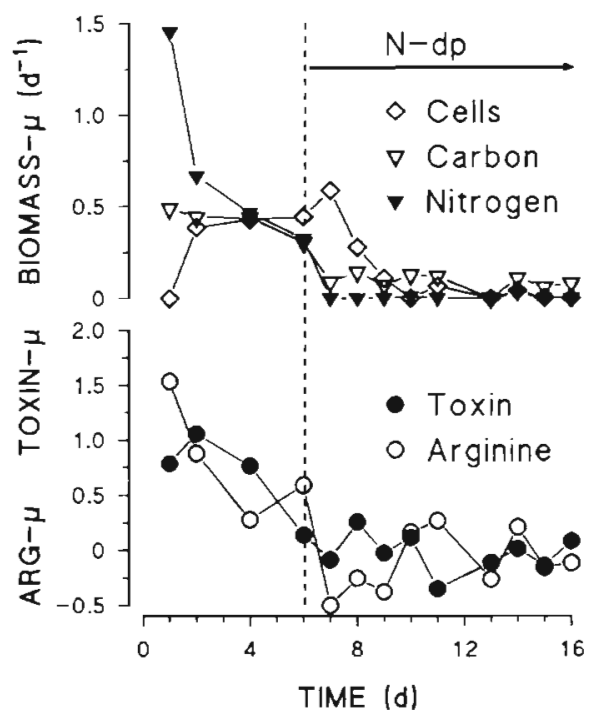

Fig. 6. Alexandrium minutum. Changes in parameter-specific rates of increase ('growth rates') for cells of AL1V grown in the low-N/high-P medium during Expt I. Cells became Ndeprived (N-dp) from Day 6. ARG: arginine 

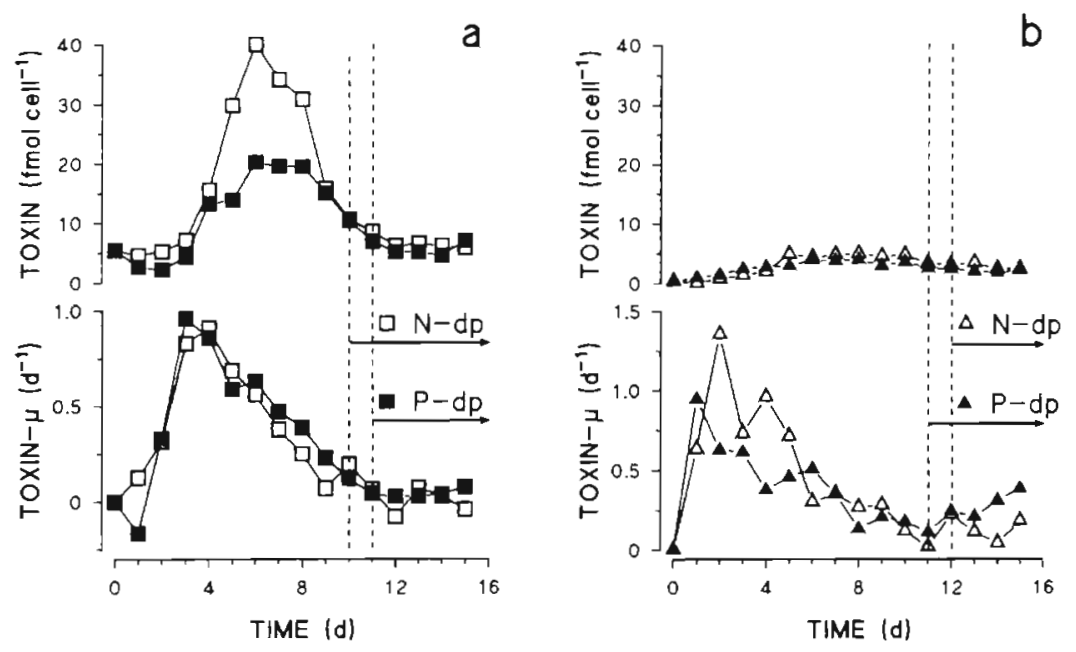

Fig. 7 Alexandrium minutum. Changes in total toxin content per cell, and in toxinspecific growth (toxin- $\mu$ ), for (a) strain AL1V and (b) strain AL2V during Expt II. Cells became $\mathrm{N}$-deprived (N-dp) or $\mathrm{P}$ deprived (P-dp) having grown in low$\mathrm{N} /$ high-P media (open symbols) or highN/low-P media (closed symbols)

hausted the phosphate, with both strains AL1V and AL2V continuing to synthesize toxin and levels of toxin cell ${ }^{-1}$ remaining high (Figs. $8 b$ \& 9b). Consistent with Expts I \& II, peak toxin cell ${ }^{-1}$ in Expt III was attained a few days after $\mathrm{N}$-refeeding of the $\mathrm{N}$ deprived cells used to inoculate these cultures. Toxin $\mathrm{C}^{-1}$ (Figs. 8c \& 9c) and toxin $\mathrm{chla}^{-1}$ (Figs. 8d \& 9d) showed similar patterns for both strains in the respec-
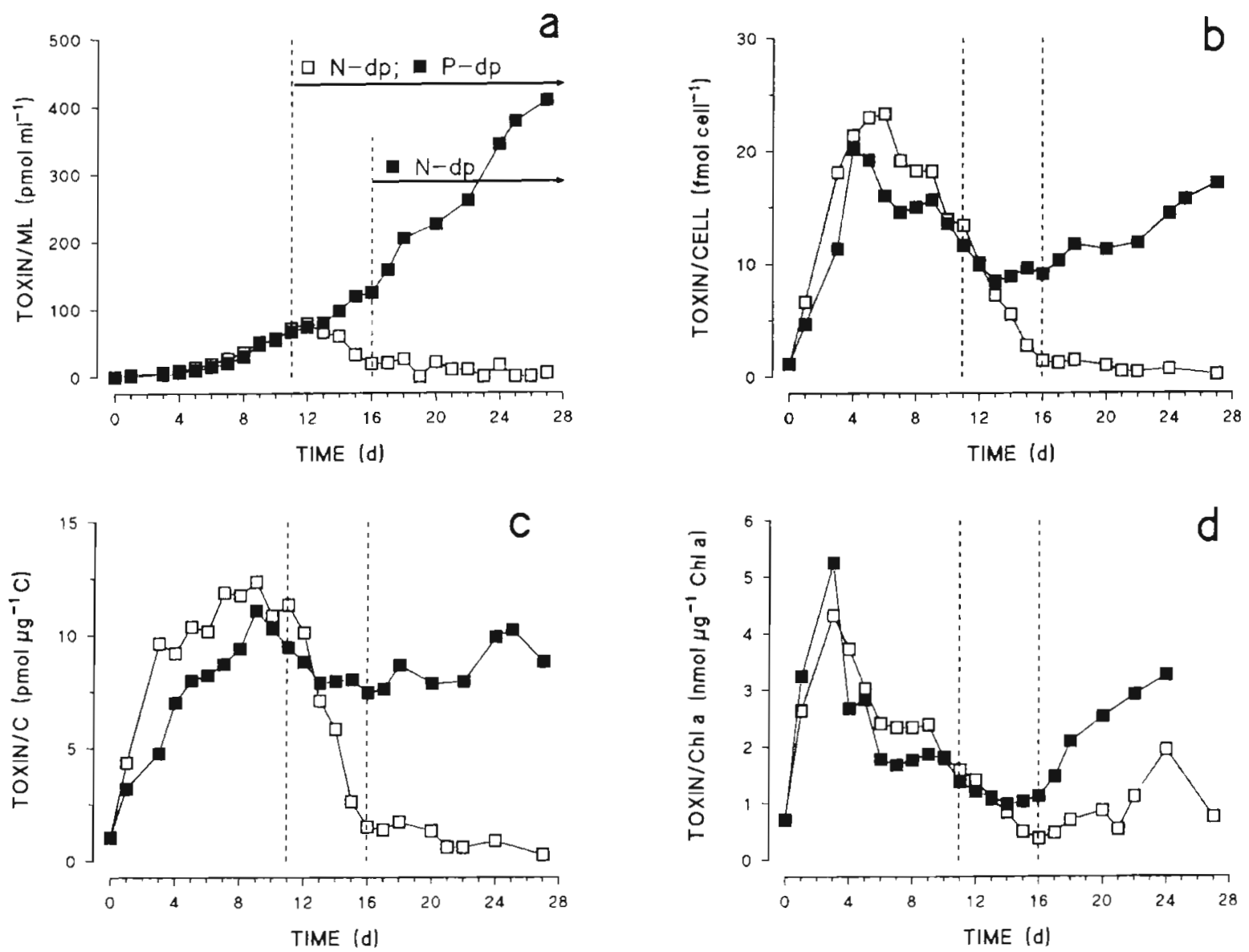

Fig. 8. Alexandrium minutum. Changes in (a) culture toxin content, (b) toxin per cell, (c) toxin per unit of cell-C and (d) toxin per unit of chl $a$, for strain AL1V during Expt III. Cells became N-deprived (N-dp) or P-deprived (P-dp) having grown in low-N/high$P$ media (open symbols) or high-N/low-P media (closed symbols) 
a
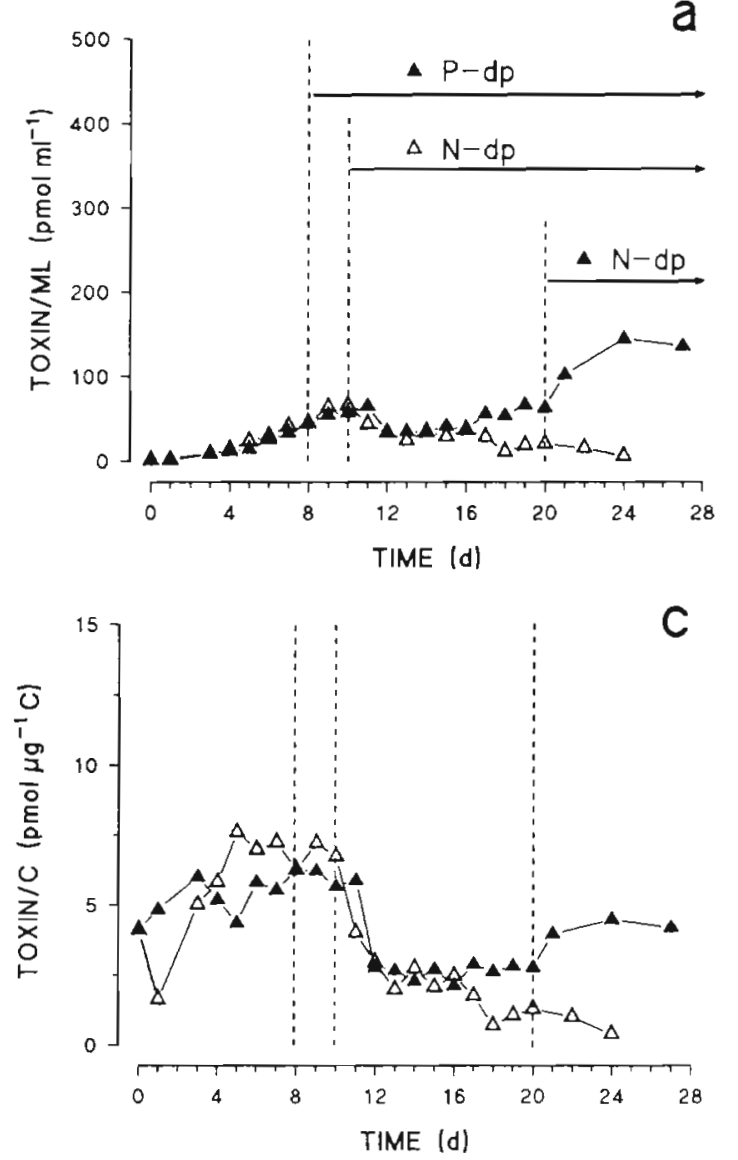
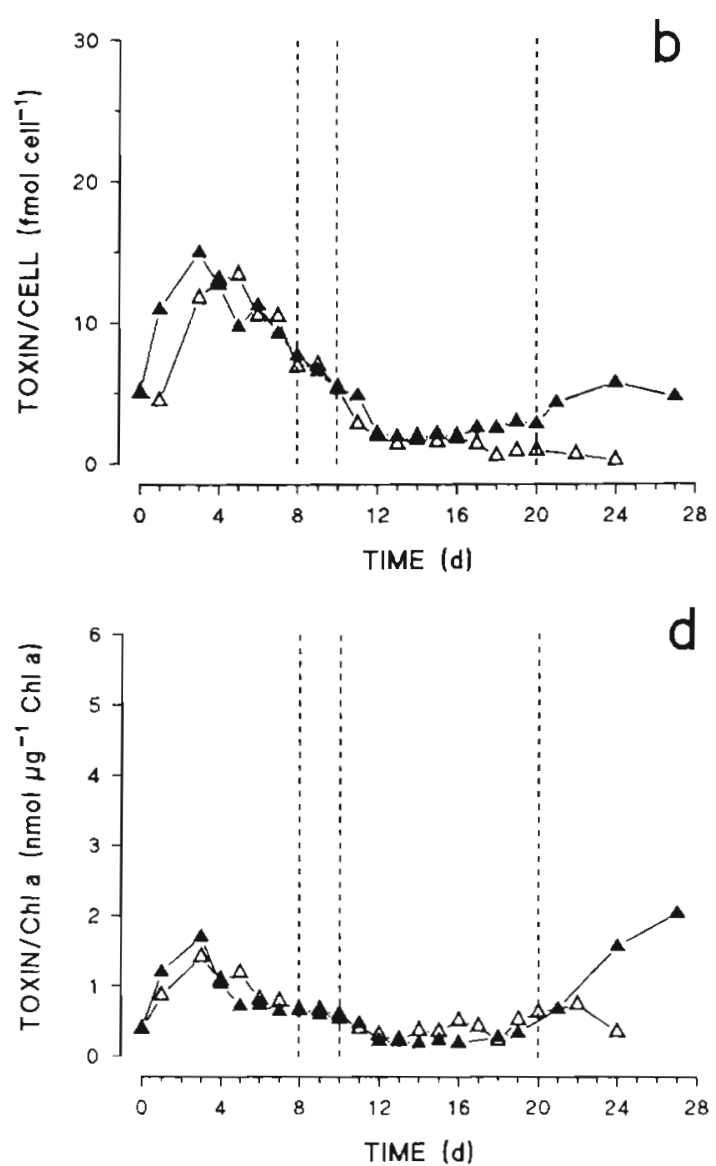

Fig. 9. Alexandrium minutum. Changes in (a) culture toxin content, (b) toxin per cell, (c) toxin per unit of cell-C and (d) toxin per unit of chl $a$, for strain AL2V during Expt III. Other details as in Fig. 8

tive nutrient regimes, with toxin $\mathrm{chl} a^{-1}$ rising late during growth in the high-N/low-P cultures due to loss of pigment per cell, while in low-N/high-P cultures the bleaching was concurrent with a loss of toxin.

The consequences of $\mathrm{P}$-deprivation prior to $\mathrm{N}$-deprivation, in comparison with $\mathrm{N}$-deprivation alone, are most apparent when toxin is considered on nitrogenous bases, either toxin $\mathrm{N}^{-1}$ (Figs. 10a \& 11a), or per unit of InAA. The responses were greater for AL1V, at least in part because this strain has a higher $\mathrm{N}$ content during $\mathrm{N}$-sufficient growth and the rise in $\mathrm{C} / \mathrm{N}$ and fall in InAA cell ${ }^{-1}$ was proportionately greater on $\mathrm{N}$-deprivation. Changes in toxin arginine ${ }^{-1}$ (Figs. 10b \& 11b) and in toxin taurine ${ }^{-1}$ (Figs. 10c \& 11c) are illustrated; glutamine and glycine showed similar trends but toxin per unit of the other $16 \mathrm{com}-$ ponents of InAA measured did not show these trends. The rises in toxin arginine ${ }^{-1}$ in the low-N/high-P cultures (open symbols in Figs. 10b \& 11b) following the onset of $\mathrm{N}$-deprivation were due to the initial fall in the cell content of arginine on exhaustion of nitrate.

\section{DISCUSSION}

\section{Effects on toxin content of $\mathrm{N}$-refeeding of $\mathrm{N}$-deprived cells}

Net toxin synthesis in Alexandrium minutum was fastest during recovery from lag phase of $\mathrm{N}$-deprived cells (Figs. 6 to 9). During that period, toxin- $\mu$ exceeded cell- $\mu$ and C- $\mu$ by a factor of 3 to 4 , giving a $\mu$ for toxin cell ${ }^{-1}\left(R_{\mathrm{tox}}\right.$ as described by Anderson et al. 1990) of $0.7 d^{-1}$. The A. fundyense cells of Anderson et al. (1990) were already in exponential phase at the start of their experiments (with low $\mathrm{C} / \mathrm{N}$ ratios), so $\mathrm{N}$ refeeding was not studied. However, while data collection by Boyer et al. (1987) commenced in earnest a few days after inoculation, there are indications that the highest values of toxin cell- in P-replete cells of $A$. (Protogonyaulax) tamarensis were attained shortly after the start of growth. The data of Boczar et al. (1988) also show the highest toxin content early in the growth curve for the same species. The implication is then that an increase in toxin cell ${ }^{-1}$ during recovery 

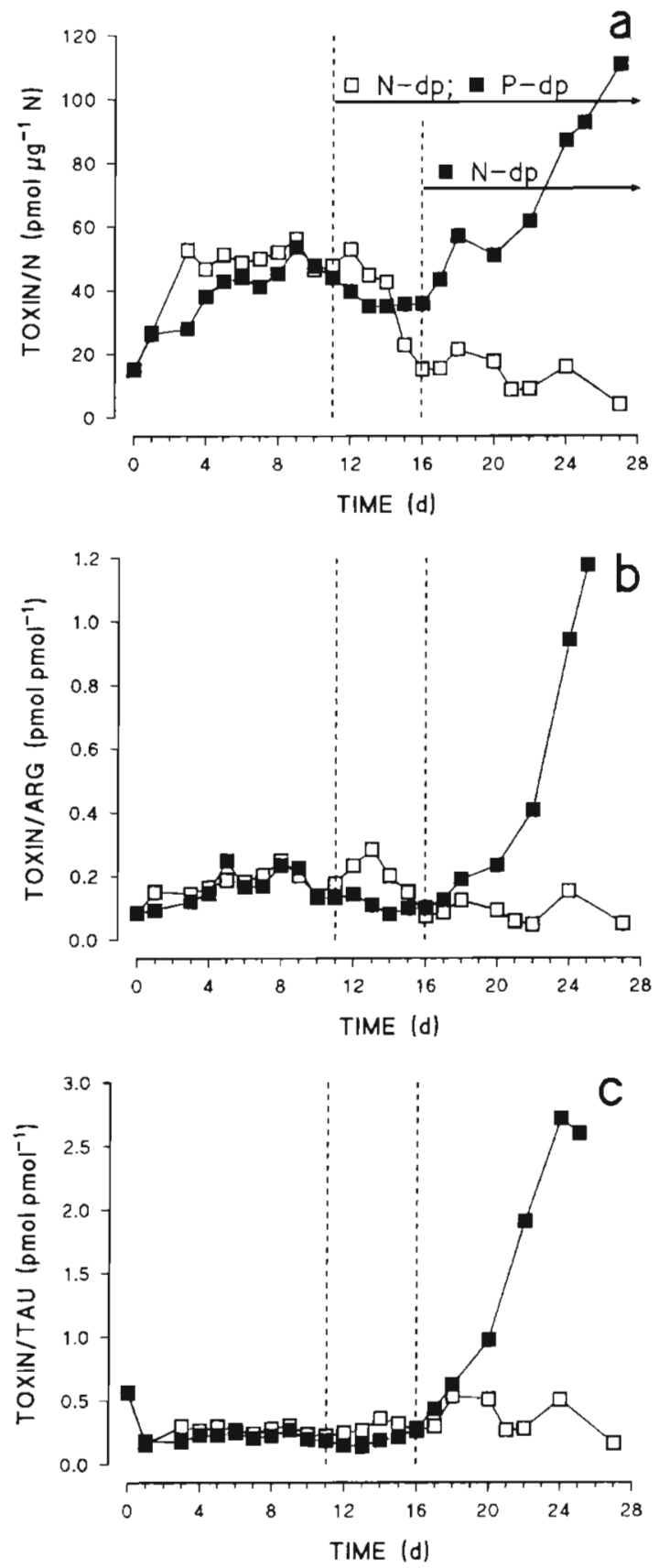

Fig. 10. Alexandrium minutum. Changes in (a) toxin per unit of cell-N, (b) toxin per unit of intracellular free arginine, and (c) toxin per unit of intracellular free taurine, for strain ALIV during Expt III. Cells became $\mathrm{N}$-deprived (N-dp) or Pdeprived $(\mathrm{P}-\mathrm{dp})$ having grown in low-N/high-P media (open symbols) or high-N/low-P media (closed symbols)

from lag phase may be typical in Alexandrium spp. Beyond that stage, there may be a broad correlation between cell- $\mu$ and toxin- $\mu$ as reported by Anderson et al. (1990), but the stability of toxin cell ${ }^{-1}$ implied by such a correlation was not apparent during our experiments.
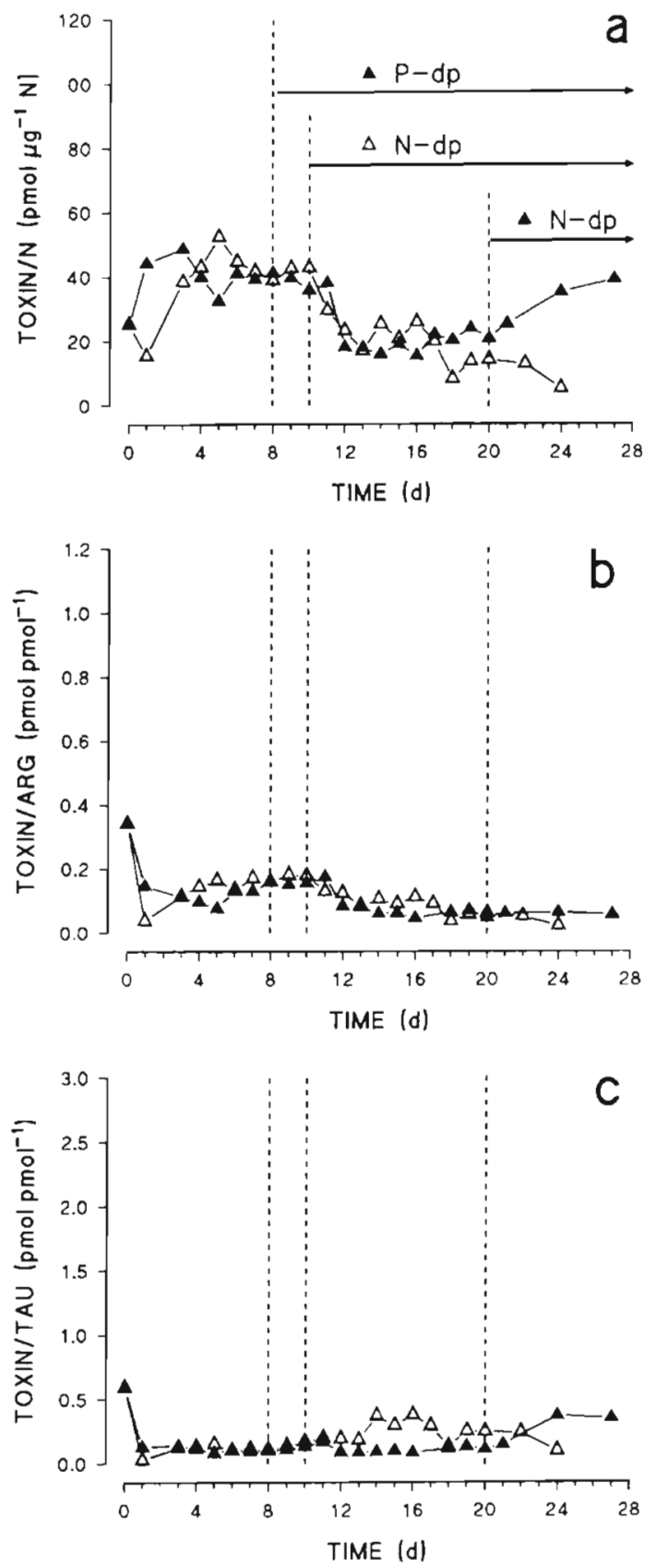

Fig. 11. Alexandrium minutum. Changes in (a) toxin per unit of cell- $N_{1}(b)$ toxin per unit of intracellular free arginine, and (c) toxin per unit of intracellular free taurine, for strain AL2V during Expt III. Other details as in Fig. 10

If maximum toxin cell ${ }^{-1}$ is associated with a transient state in $\mathrm{C}-\mathrm{N}$ physiology, then one has to question the response of natural populations, especially of $\mathrm{N}$ stressed cells, coming into contact with elevated nutrients in coastal waters or from riverine inputs (Franks \& Anderson 1992). One may suspect that events such as the relaxation of C-stress (Ogata et al. 1987) or Festress (Doucette \& Harrison 1991), which must affect 
amino acid synthesis, also have knock-on effects on the synthesis of nitrogenous toxins. The consequences of $\mathrm{N}$-refeeding or P-refeeding of toxin-producing cells which are P-stressed need to be investigated.

As arginine is a precursor of paralytic shellfish toxins (Shimizu et al. 1990), and is also a protein amino acid (and thus contributes towards cell-N), one may expect to see an association between changes in cell- $\mathrm{N}$, arginine and toxin contents. A comparative plot of cell- $\mu$, $\mathrm{C}-\mu, \mathrm{N}-\mu$, arginine- $\mu$ and toxin- $\mu$ (Fig. 6) supports the suggestion of a link between an upshock in $\mathrm{N}$-status of the cells and toxin synthesis which, because cell number, $C$-biomass and $N$-biomass increases are not coupled, results in an increase in toxin cell ${ }^{-1}$. However, a few other amino acids such as taurine (Fig. 10c) show a similar relationship to toxin. In addition, the arginine contents of the 2 strains of Alexandrium minutum cover similar ranges while the mole ratios of toxin/arginine were 1 for AL1V and 0.2 for AL2V in Expt II, but varied between 0.1 and 1.2 in Expt III (Figs. $10 \mathrm{~b} \& 11 \mathrm{~b}$ ). This suggests that trying to link factors which affect the content of free arginine to that of toxin may be less than simple, and that availability of free arginine alone is not the controlling factor in toxicity within this species.

\section{Effects on toxin content of $\mathrm{N}$-deprivation and P-deprivation}

That $\mathrm{N}$-stress affects paralytic shellfish toxin content has been recorded before (Boyer et al. 1987. Anderson et al. 1990). As amino acids are intermediates in toxin synthesis, a decline in net toxin synthesis during $\mathrm{N}$ deprivation may be expected. During Expt III, cells of Alexandrium minutum showed a significant decline in toxin content during $\mathrm{N}$-deprivation (Figs. 8b \& 9b), suggesting not only a cessation of synthesis but perhaps an active turnover. Interestingly, that process was inhibited in cells P-stressed before they were $\mathrm{N}$ stressed (Figs. 10a \& 11a), implicating $P$ in the regulation of toxin metabolism. Phosphorylation of enzymes is a common mode of metabolic regulation, and phosphorylation of metabolic intermediates is also very common, so there must be many points at which $\mathrm{P}$. stress could affect toxin metabolism.

P-stress affects amino acid synthesis in Alexandrium spp. (K. Flynn \& K. J. Flynn unpubl.), leading to a decline in InAA content. It may be expected that, as the intracellular pool of arginine declines during $\mathrm{P}$ stress that the synthesis of toxins may also be adversely affected. However, both Boyer et al. (1987) and Anderson et al. (1990) report enhanced toxin synthesis by Alexandrium spp. in response to P-deprivation, while we found no indication of that for our strains of $A$. min- utum. The experiment of Boyer et al. (1987) was of sufficient duration to unequivocally create P-limited growth. The experiments of Anderson et al. (1990) and those reported here for Expt I and II used much shorter periods of P-stress which may or may not have been effectual. Expt III did expose cells to prolonged P-stress, though this was associated with a degree of $\mathrm{N}$-stress as well. Alkaline phosphatase activity in $A$. minutum does not develop for several days after exhaustion of nutrient-P (K. Flynn \& K. J. Flynn unpubl.). This is not uncommon because of the use of previously accumulated intracellular $P$ and because of the delay in synthesis of the enzyme (Flynn et al. 1986). The concept of P-stress and its application to the problem of dinoflagellate toxicity is thus complicated by an incomplete knowledge of the level of P-stress at the point of cellular metabolism.

Laboratory cultures of dinoflagellates are often maintained in nutrient regimes with very high nitrate concentrations relative to phosphate (e.g. N/P of 88 in the K-medium of Keller \& Guillard 1985). However, it is extremely unlikely that natural populations would be exposed to N/P ratios of that order, so any induction of high toxicity by this route could be a laboratory phenomenon. Coupled with the fact that cultured dinoflagellates often cease growth when there are still excess amounts of macronutrients present in the medium, the highest values of toxin $\mathrm{ml}^{-1}$ of culture (though perhaps not their highest value of toxin cell-1) may be attained after prolonged incubation.

Growth rates, cell sizes and toxin content for Alexandrium minutum vary depending on the culture media and the method of sterilization (J. M. Franco et al. unpubl.), with the fastest initial rates of growth and toxin content being seen in filter-sterilized K-media (Keller \& Guillard 1985). Franco et al. (1992) document quantitative differences between the toxin profiles for the 2 strains AL1V and AL2V, showing that AL1V can exhibit as much as 20 times the GTX content detected in AL2V, although (perhaps significantly) those experiments were conducted at higher temperatures. Cells at lower temperature grow slower and are more toxic (Ogata et al. 1987, Anderson et al. 1990), but the degree of enhancement may vary between strains and species.

The work of Cembella et al. (1987) indicates the wide diversity of toxin profiles in Alexandrium (Protogonyaulax) spp.; some strains contain significant amounts of GTX while others contain very little. HPLC analyses of toxins from wild populations of $A$. minutum collected at different times and in different rias in Galicia also show a profile dominated by 80 to $90 \%$ GTX 4 and 5 to $10 \%$ GTX1, with smaller amounts of GTX2 and GTX3, trace amounts of $\mathrm{C}$ toxins and no STX or neoSTX (Franco et al. 1992). There is some uncertainty 
over changes in toxin profiles during the growth of individual strains (Boyer et al. 1987, Boczar et al. 1988). We noted only minor changes (10\% or so) in the toxin profile during Expt I.

\section{Difierences between strains AL1V and AL2V}

The differences between biomass, InAA content and pigmentation of the 2 strains of Alexandrium minutum do not appear to be profound. Cells of AL2V had a higher exponential-phase $\mathrm{C} / \mathrm{N}$ ratio, though average cell sizes were similar, and had on average a higher InAA content, although this decreases in response to both N-deprivation and P-deprivation (Flynn \& Flynn unpubl.). Thus, in Expt II and Expt III total InAA-N in AL1V decreased from 4 to $2 \%$ of cell-N, and for AL2V, from 6 to $4 \%$, during nutrient deprivation. In all cases, cultures which depleted their nitrate showed a more rapid loss of InAA-N per cell than those which had exhausted phosphate.

There were significant, though low-magnitude, differences in the proportions of chl $c_{2}$ and peridinin relative to chl $a$ in the 2 strains. It is of interest that the carotenoids, peridinin, diadinoxanthin and dinoxanthin, covaried with chl a for both strains. While chl $c_{2}$ and peridinin are light-harvesting pigments in dinoflagellates (and so may be expected to covary with chl a), diadinoxanthin and dinoxanthin are suggested to have photo-protective functions (Prezelin \& Boczar 1986). Although Demers et al. (1991) observed a rapid lightinduced change in xanthophyll cycle pigments in Alexandrium excavatum, the epoxy-free diatoxanthin (formed by conversion of diadinoxanthin) was not detected in either strain of $A$. minutum. This could be due to the photon flux density (PFD) employed

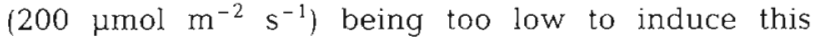
response; the ratio of $\mathrm{chl}$ a/diadinoxanthin was similar to that reported for $A$. excavatum growing at $50 \mu \mathrm{mol}$ $\mathrm{m}^{-2} \mathrm{~s}^{-1}$ (Demers et al. 1991). Net C-fixation rates, computed from increases in algal $C$ each day, peaked at around $0.3 \mathrm{ng} \mathrm{C}$ cell ${ }^{-1} \mathrm{~d}^{-1}\left(0.025 \mathrm{ng} \mathrm{C}\right.$ cell ${ }^{-1} \mathrm{~h}^{-1}$ over the $12 \mathrm{~h}$ light phase). These values are at the lower end of the range given by Glibert et al. (1988) for $A$. (Gonyaulax) tamarensis at a PFD of $200 \mu \mathrm{mol} \mathrm{m} \mathrm{m}^{-2} \mathrm{~s}^{-1}$, although this may well reflect a difference in cell size. A complicating factor here is that flagellates, including dinoflagellates, often swim to form dense swarms in which the PFD available to the individual may be lowered significantly. This may affect the $\mathrm{C}-\mathrm{N}$ status of the cells.

Pigments could not be used as estimators of biomass or toxicity for Alexandrium minutum. Although the regression coefficients ( $r$ ) for plots of cell number, biomass and toxicity against chl a for Expt II were all sig- nificant, the coefficients of variation for the entire data sets for Expt II, for cell/chl a (41\%), carbon/chl a (55\%), nitrogen/chl a $(54 \%)$ and toxin/chla $(93 \%)$ were so large that predictive equations would be worthless. Even for individual cultures, the coefficients of variation were between $20 \%$ and $50 \%$. Temporal variations in toxin chl $\mathrm{a}^{-1}$ can be seen for Expt III in Figs. 8d \& 9d.

Acknowledgements. This work was supported by research and capital equipment grants from the Natural Environment Research Council (UK) to K.J.F., funds from project ALI920111-CO2-01 (CICYT) to J.M.F and project 11.02 (IEO) to B.R. We thank Y. Pazos for assistance with Expt $I I$, and S. J. Wainwright for advice on statistical matters.

\section{LITERATURE CITED}

Anderson, D. M., Kullis, D. M., Sullivan, J. J., Hall, S, Lee, C. (1990). Dynamics and physiology of saxitoxin production by the dinoflagellates Alexandrium spp. Mar. Biol. 104: $511-524$

Blanco, J. J., Marino, L., Campos, M. J. (1985). The first toxic bloom of Gonyaulax tamarensis detected in Spain (1984). In: Anderson, D. M., White, A. W., Baden, D. G. (eds.) Toxic dinoflagellates. Elsevier, New York, p. 79-84

Boczar, B. A., Beitler, M. K., Liston, J., Sullivan, J. J., Cattolico, R. A. (1988). Paralytic shellfish toxins in Protogonyaulax tamarensis and Protogonyaulax catenella in axenic culture. Plant Physiol. 88: $1285-1290$

Boyer, G. L., Sullivan, J. J., Andersen, R. J., Harrison, P. J., Taylor, F. J. R. (1987). Effects of nutrient limitation on toxic production and composition in the marine dinoflagellate Protogonyaulax tamarensis. Mar. Biol. 96: 123-128

Cembella, A. D., Sullivan, J. J., Boyer, G. L., Taylor, F. J. R., Andersen, R. J. (1987). Variations in paralytic shellfish toxin composition within the Protogonyaulax tamarensis/catenella species complex; red tide dinoflagellates. Biochem. Syst. Ecol. 15: 171-186

Delgado, M., Estrada, M., Camp, J., Fenández, J. V., Santmartí, M., Lleti, C. (1990). Development of a toxic Alexandrium minutum Halim bloom in the harbour of Sant Carles de la Rapita. Scientia mar. 54: 1-7

Demers, S., Roy, S., Gagnon, R., Vignoult, C. (1991). Rapid light-induced changes in cell fluorescence and in xanthophyll-cycle pigments of Alexandrium excavatum (Dinophyceae) and Thalassiosira pseudonana (Bacillariophyceae); a photo-protection mechanism. Mar. Ecol. Prog Ser. 76: $185-194$

Doucette, G. J., Harrison, P. J. (1991). Aspects of iron and nitrogen nutrition in the red tide dinoflagellate Gymnodinium sanguineum. II. Effects of iron depletion and nitrogen source on iron and nitrogen uptake. Mar. Biol. 110 $175-182$

Erard-Le Denn, E. (1991). Alexandrium minutum (Dinophycées). In: Sournia, A., et al. (eds.) Le phytoplancton nuisible des côtes de France: de la biologie à la prévention. IFREMER, Brest, p. 83-90

Flynn, K. J., Flynn, K. (1992). Non-protein free amines in microalgae: consequences for the measurement of intracellular amino acids and of the glutamine/glutamate ratio. Mar. Ecol. Prog. Ser. 89: 73-79

Flynn, K. J., Zapata, M., Garrido, J. L., Öpik, H., Hipkin, C. R. (1993). Changes in carbon and nitrogen physiology during ammonium and nitrate nutrition and nitrogen starvation in Isochrysis galbana. Eur. J. Phycol. 28: 47-52 
Flynn, K. J., Öpik, H., Syrett, P. J. (1986). Localization of the alkaline phosphatase and 5 -nucleotidase activities of the diatom Phaeodactylum tricornutum. J. gen. Microbiol. 132: $289-298$

Franco, J. M., Fernández, P., Reguera, B. (1992). The toxin profile of Alexandrium lusitanicum Balech from the Atlantic coast of the Iberian Peninsula. Comm. Meet. Int. Coun. Explor. Sea C.M.-ICES/L: 42

Franco, J. M., Fernández-Vila, P. (1993). Separations of paralytic shellfish toxins by reversed phase high performance liquid chromatography, with postcolumn reaction and fluorometric detection. Chromatographia 35: 613-620.

Franks, P. J. S., Anderson, D. M. (1992). Alongshore transport of a toxic phytoplankton bloom in a buoyancy current Alexandrium tamarense in the Gulf of Maine. Mar. Biol. 112: $153-164$

Glibert, P. M., Kana, T. M., Anderson, D. M. (1988). Photosynthetic responses of Gonyaulax tamarensis during growth in a natural bloom and in batch culture. Mar. Ecol. Prog. Ser. 42: 303-309

Hallegraeff, G. M., Bolch, C. J., Blackburn, S. I., Oshima, Y. (1991). Species of the toxigenic dinoflagellate Alexandrium in southeastern Australian waters. Botanica mar. 34 : $575-587$

Holligan, P. M., Williams, P. J. LeB., Purdie, D., Harris, R. P. (1984). Photosynthesis, respiration and nitrogen supply of plankton populations in stratified, frontal and totally mixed shelf waters. Mar. Ecol. Prog. Ser. 17: 201-213

Jeffrey, S. W., Humphrey, G. F. (1975). New spectrophotometric equations for determining chlorophylls $a, b, c_{1}$ and $c_{2}$ in higher plants and natural phytoplankton. Biochem. Biophys. Pflanz. 167: 191-194

Jeffrey, S. W., Sielicki, M., Haxo, T. (1975). Chloroplast pigment patterns in dinoflagellates. J. Phycol. 11: 374-384

Keller, M. D., Guillard, R. R. L. (1985). Factors significant to marine dinoflagellate culture. In: Anderson, D. M., White, A. W., Baden, D. G. (eds.) Toxic dinoflagellates. Elsevier, New York, p. 113-116

Lawrence, J. F., Ménard, C., Charbonneau, C. F., Hall, S. (1991). A study of ten toxins associated with paralytic shellfish poison using prechromatographic oxidation and liquid chromatography with fluorescence detection. J Ass. Off. Anal. Chem. 74: 404-409

This article was submitted to the editor
LeFévre, J. (1986). Aspects of the biology of frontal systems Adv. mar. Biol. 23: $163-299$

Margalef, R. (1978). Life-forms of phytoplankton as survival alternatives in an unstable environment. Oceanol. Acta 1: 493-509

Margalef, R., Estrada, M., Blasco, D. (1979). Functional morphology of organisms involved in red tides as adapted to decaying turbulence. In: Taylor, D. L., Seliger, H. H. (eds.) Toxic dinoflagellate blooms. Elsevier, Amsterdam, p. 89-94

Montresor, M., Marino, D., Zingone, A., Dafnis, G. (1990). Three Alexandrium species from coastal Tyrrhenian waters (Mediterranean Sea). In: Granéli, E., Sundström, B., Edler, L., Anderson, D. M. (eds.) Toxic marine phytoplankton. Elsevier, New York, p. 82-87

Ogata, T., Ishimaru, T., Kodama, M. (1987). Effect of water temperature and light intensity on growth rate and toxicity changes in Protogonyaulax tamarensis. Mar. Biol. 95: $217-220$

Paasche, E., Bryceson, I., Tangen, K. (1984). Interspecific variation in dark nitrogen uptake by dinoflagellates. J. Phycol. 20: $394-401$

Prezelin, B. B., Boczar, B. A. (1986). Molecular bases of cell absorption and fluorescence in phytoplankton: potential applications to studies in optical oceanography. In: Round, F., Chapman, G. (eds.) Progress in phycological research 4. Biopress Ltd, Bristol, p. 350-450

Reguera, B., Campos, M. J., Fraga, S., Marin̄o, J., Bravo, I. (1991). The monitoring of harmful algal blooms in Galicia (NW Spain). In: Fremy, J. (ed.) Colloque Internationale des Biotoxines Marines. Centre National d'Etudes Vétérinaires et Alimentaires, Paris, p. 217-223

Shimizu, Y., Gupta, S., Pradad, A. V. K. (1990). Biosynthesis of dinoflagellate toxins. In: Granéli, E., Sundström, B., Edler, L., Anderson, D. M. (eds.) Toxic marine phytoplankton. Elsevier, New York, p. 62-71

Strickland, J. D. H., Parsons, T. R. (1972). A practical handbook of seawater analysis. Bull. Fish. Res. Bd Can. 167: $1-311$

Zapata, M., Ayala, A. M., Franco, J. M., Garrido, J. L. (1987). Separation of chlorophylls and their degradation products in marine phytoplankton by reversed-phase high performance liquid chromatography. Chromatographia 23: $28-30$

Manuscript first received: August 4, 1993

Revised version accepted: April 8, 1994 